\section{German Institute of Psychological Research}

A GERman Institute of Psychological Research and Psychotherapy has been founded under the auspices of the German Home Office. The members consist of representatives of the Pan-German Medical Society of Psychotherapy, the German Psychoanalytic Society, the Künkel co-operative group for "Applied Study of Character" and other well-known psychotherapeutists. The functions of the Institute will be (1) research, (2) educational and teaching activities, and (3) maintenance of a clinic for the indigent. The director is Prof. M. G. Göring, president of the Pan-German Medical Society of General Psychotherapy.

\section{Public Health Investigation in India}

Two Indian institutes have recently issued their reports. That of the All-India Institute of Hygiene and Public Health, Calcutta, for 1935 reviews the courses of instruction that have been given and summarizes the research work carried out. The lastnamed includes epidemiological studies on cholera and studies upon the chemical constitution of the cholera vibrios by Dr. Linton, the epidemiology of epidemic dropsy and the ætiology of black-water fever. Diet surveys of certain sections of the population and field studies upon malaria have also been carried out. The second report, that of the Haffkine Institute, summarizes the Institute's work for 193235. Plague investigations have been continued, and more than two million doses of plague vaccine were issued in 1933-34; Drs. Sokhey and Maurice have prepared a curative plague serum which experimentally possesses greater potency than any sera previously prepared. Anti-rabic treatment is also provided at the Institute, and 2,274 cases were treated during 1935, with a mortality rate of 0.17 per cent.

\section{Natural and Artificial Manures}

The Ministry of Agriculture has issued a new and enlarged edition of Bulletin 36, "Manures and Manuring" (H.M. Stationery Office, price 2s.). A number of additions have been made since the last issue, the preliminary section dealing with the principles that govern the manuring of farm crops having been specially expanded. As before, the bulletin is divided into three main sections, namely, organic manures, artificial fertilizers and the purchase and use of artificial manures. The information is essentially practical, and should enable the farmer to make the fullest use of the wide variety of fertilizers now available. In view of the differences in local conditions, complete generalizations are of course impossible, and in the event of uncertainty the farmer is advised to consult the agricultural organizer for the county in which he resides. A pamphlet (Form A. 705/TG.) giving names and addresses of advisory staffs may be obtained free on application to the Secretary of the Ministry of Agriculture, 10 Whitehall Place, London, S.W.I.

\section{Broadcasting of Cosmic Data}

A REGUlar schedule of broadeasts of cosmic data and scientific news was inaugurated at Boston, U.S.A., on February 1 by the World Wide Broadcasting Foundation's short-wave station in co-operation with the Union Radio Scientifique International and Science Service. The primary purpose of these broadcasts is to make available internationally technical data on observations of sunspots, solar radiation, magnetism, ionized layer heights and other phenomena observed during the same day, and to interest laymon in making observations. The broadcasts will be heard daily from 4.55 to 5.00 p.m. (Eastern Standard Time) on 25.4 metres and weekly summaries on Monday evenings from 8.30 until 8.45 p.m. on $49 \cdot 6$ metres. The Monday evening broadcasts will be a weekly compilation. The programme inaugurating this service included brief talks by Dr. A. E. Kennelly of Harvard University, the codiscoverer of the Kennelly-Heaviside layer; Dr. Harlow Shapley, director of the Harvard College Observatory, and Watson Davis, director of Science Service, Washington.

\section{Science Abstracts}

THe issue of the two index numbers of vols. 39 of Science Abstracts for 1936 enables a comparison to be made with previous volumes. The physics volume includes 5,716 abstracts covering 1,332 pages, with a subject index of nearly 260 and an author index of more than 80 pages. The electrical engineering volume has 3,525 abstracts in 820 pages, with subject index 120 and the author index 55 pages. The former volume is about six per cent larger than last year's and the latter about eleven per cent. The average length of the abstracts is slightly less than last year. The subject index in the physics volume has a key to it which facilitates its use. Each volume of Science Abstracts is a valuable time-saving device for those who wish to keep abreast of research or look up past progress in the subject with which it deals.

\section{Prof. T. C. Hodson: a Correction}

Prof. T. C. Hodson writes to point out in reference to the announcement of his impending retirement from the professorship of social anthropology in the University of Cambridge (see Nature, March 20, p. 497), that he did not take a degree at Queen's College, Oxford, and that during the War, his service with the Indian forces covered a brief period only, when he was transferred to Railways and later to Forestry G.H.Q., where he took over from the late Lord Lovat. It should be added that Prof. Hodson was honorary secretary of the Royal Anthropological Institute in 1912-1914-15.

\section{Comet Whipple (1937b)}

Using observations made at Harvard on February 4, at Norwood on February 26 by Steavenson, and on March 11 and 12 by Hay at Hendon and Steavenson at Norwood, respectively, the Rev. Dr. M. Davidson has computed the following orbit : $T, 1937$ 